\title{
PKM BAGI PELAJAR TENTANG KESADARAN HUKUM DALAM MENINGKATKAN PENGETAHUAN BERLALU LINTAS DI SMK KRISTEN GETSEMANI MANADO
}

\author{
Yoan Barbara Runtunuwu \\ Prodi Ilmu Hukum, Fakultas Ilmu Sosial \\ Universitas Negeri Manado \\ Email: yoanruntunuwu@unima.ac.id
}

\begin{abstract}
Education is a conscious and planned effort to create an atmosphere of learning and learning process so that students actively develop their potential to have religious spiritual power, self-control, personality, intelligence, noble character, and the skills needed by themselves, society, nation and state (Law Number 20 The 2003 National Education System. SMK Kristen Getsemani is one of the vocational schools located in the city of Manado, precisely located in Sario Subdistrict. This issue of legal awareness arose initially in connection with efforts to find a basis rather than the validity of a legal regulation as a result of various problems that arise in the context of applying a legal provision Then this develops and causes a problem in the legal basis of a legal provision, is it based on the orders of the authorities or based on awareness and society? There are many legal provisions in the community which are not obeyed by the community. In order for a professional harmony between the applied law and the legal awareness of the community, the regulation itself. Legal awareness is as awareness or values contained in human beings about existing traffic laws or the expected legal concerns Traffic in Law Number 22 Year 2009 is defined as the movement of awareness and people in the road traffic space. Traffic legal awareness is a condition in which individuals have full awareness of traffic laws that have been established with the expectation that the use of traffic can be controlled in the situation of traffic so that unwanted things occur.
\end{abstract}

Keywords: Legal Awareness, Traffic, SMK Kristen Getsemani 


\section{PENDAHULUAN}

Pendidikan kejuruan termasuk dalam pendidikan teknologi dan kejuruan seperti dijelaskan dalam UU No 20 Tahun 2003(UndangUndang Nomor 20 Tahun 2003 Tentang Sistem Pendidikan Nasional, n.d.) bahwa pendidikan teknologi dan kejuruan dibagi menjadi 3 bagian, yaitu: (1) Pendidikan Kejuruan, adalah pendidikan menengah yang mempersiapkan peserta didik terutama untuk bekerja pada bidang tertentu; (2) Pendidikan profesi, adalah pendidikan tinggi setelah program sarjana yang mempersiapkan peserta didik untuk memiliki pekerjaan dengan persyaratan khusus; dan (3) Pendidikan vokasi, adalah pendidikan tinggi yang mempersiapkan peserta didik untuk memiliki pekerjaan dengan ke ahlian terapan tertentu, maksimal setara dengan program sarjana.

Pengertian pendidikan kejuruan yang dikemukakan oleh Sbedden (dalam Majid, 2012), yaitu pendidikan kejuruan adalah pendidikan yang diarahkan untuk mempelajari bidang khusus, agar para lulusan memiliki keahlian tertentu seperti bisnis, pabrikasi, pertanian, kerumahtanggaan, otomotif, listrik, bangunan, dan sebagainya. selanjutnya Majid (2012) mengemukakan bahwa pendidikan teknologi dan kejuruan adalah pendidikan yang diselenggarakan bagi para peserta didik yang merencanakan dan mengembangkan karirnya pada bidang keahlian tertentu untuk bekerja secara produktif dan profesional juga siap melanjutkan ke tingkat pendidikan yang lebih tinggi.

Pelaksanaan pendidikan di Indonesia harus didasari dari landasan yuridis. Hal ini juga berlaku bagi pelaksanaan SMK. Landasan yuridis SMK, berdasarkan pada:

a. UUD 1945(Undang-Undang Dasar Negara Republik Indonesia Tahun 1945, n.d.) mengamanatkan kepada pemerintah melalui usaha penyelenggaraan sistem pendidikan nasional untuk meningkatkan keimanan dan ketaqwaan serta akhlak mulia dalam rangka mencerdaskan kehidupan bangsa yang diatur pada Undang-undang.

b. Undang-undang Nomor 20 Tahun 20 Tentang Pendidikan Nasional Republik Indonesia. Pada pasal 15 dijelaskan bahwa SMK merupakan pendidikan menengah yang mempersiapkan peserta didik terutama dalam bidang pekerjaan tertentu, dan pada pasal 38 dikatakan kerangka dasar dan struktur pendidikan dasar dan menengah ditetapkan pemerinth melalui Badan Standar Nasional Pendidikan (BSNP). c. Keputusan Menteri Pendidikan dan Kebudayaan Nomor 323/U/1997 tentang Penyelenggara Pendidikan Sistem Ganda di SMK.

d. Peraturan Menteri Pendidikan Nasional (Permendiknas) Nomor 22 Tahun 2006 tentang Standar Isi

e. Peraturan Menteri Pendidikan Nasional Nomor 23 Tahun 2006 Tentang Standar Kompetensi Kelulusan

f. Peraturan Menteri Pendidikan Nasional Nomor 24 Tahun 2006 tentang Pedoman Pelaksanaan Permendiknas Nomor 22 dan Nomor 23 tentang standar Isi dan Standar Kelulusan, dan

g. Ketentuan lain yang berhubungan dengan penyelenggaraan pendidikan dan pelatihan yang dilaksanakan pada SMK.

Standar kompetensi untuk mata pelajaran ilmu pengetahuan dan teknologi bagi SMK/MAK yang dijelaskan oleh Badan Standar Nasional Pendidikan (2006), adalah:

a. Membangun dan menerapkan informasi, pengetahuan, dan teknologi secara logis, kritis, kreatif, dan inovatif;

b. Menunjukkan kemampuan berpikir logis, kritis, kreatif dan inovatif secara mandiri;

c. Menunjukkan kemampuan mengembangkan budaya belajar untuk pemberdayaan diri;

d. Menunjukkan sikap kompetitif, sportif, dan etos kerja untuk mendapatkan hasil yang baik dalam bidang ilmu pengetahuan dan teknologi (Iptek);

e. Menunjukkan kemampuan menganalisis dan memecahkan masalah kompleks;

f. Menunjukkan kemampuan menganalisis fenomena alam dan sosial kekahasan daerah masing-masing;

g. Memanfaatkan lingkungan secara produktif dan bertanggung jawab;

h. Berkomunikasi dan berinteraksi secara efektif dan santun melalui berbagai cara termasuk pemanfaatan teknologi informasi;

i. Menunjukkan keterampilan menyimak, membaca, menulis, dan berbicara dalam bahasa Indonesia dan Inggris; dan

j. Menguasai kompetensi program keahlian dan kewirausahaan, baik untuk memenuhi tuntutan dunia kerja maupun untuk mengikuti pendidikan tinggi sesuai dengan kejuruannya.

Kesadaran hukum ialah sebagai kesadaran atau nilai-nilai yang terdapat di dalam diri manusia tentang hukum berlalu lintas yang ada atau tentang hukum yang 
diharapkan.(Meretokusumo, 2008) Lalu lintas dalam UU Nomor 22 Tahun 2009 (UndangUndang Nomor 22 Tahun 2009 Tentang Lalu Lintas dan Angkutan Jalan, n.d.) didefinisikan sebagai gerak kesadaran dan orang di ruang lalu lintas jalan. Kesadaran hukum berlalu lintas adalah kondisi dimana individu memiliki kesadaran penuh terhadap hukum berlalu lintas yang telah ditetapkan dengan harapan pengguna jalan dapat terkontrol dalam keadaan berlalu lintas agar tidak terjadi hal-hal yang tidak diinginkan.(Soekanto, 1992)

Siswa SMK Kristen Getsemani Manado ratarata menggunakan kendaraan ke sekolah. Masih terdapat beberapa siswa/I yang tidak menggunakan alat keselamatan yang benar, misalnya helm dengan alasan jarak antara sekolah dengan rumah tidak terlalu jauh. Selain itu tingkat kecepatan berkendara siswa/I yang melampaui batas kecepatan juga merupakan faktor lain untuk dilakukannya penyuluhan/sosialisasi kesadaran hukum berlalu lintas ini.

\section{RUMUSAN MASALAH}

Berdasarkan observasi masih kurangnya pengetahuan tentang kesadaran hukum berlalu lintas; masih ada peserta didik yang belum mengetahui dengan jelas tentang peraturan lalu lintas yang berlaku di hukum Indonesia; masih banyak terjadi pelanggaran-pelanggaran yang sering dilakukan oleh pengendara; masih kurangnya pemahaman akan dampak pelanggaran lalu lintas dan denda yang diberikan sebagai bentuk sanksi akibat melakukan pelanggaran.

\section{SOLUSI DAN TARGET LUARAN 3.1 Solusi}

Berdasarkan permasalahan yang dikemukakan pada $\mathrm{BAB} 2$ sehingga menjadi solusi maka siswa-siswi perlu diberikan:

a. Penjelasan untuk memahami tentang peraturan lalu lintas yang berlaku di hukum Indonesia;

b. Pemahaman tentang pelanggaranpelanggaran yang sering dilakukan oleh pengendara serta penyebabnya;

c. Pengetahuan tentang dampak pelanggaran lalu lintas;

d. Pengetahuan tentang denda yang diberikan sebagai bentuk sanksi akibat melakukan pelanggaran;

e. Penyuluhan hukum mengenai kesadaran hukum berlalu lintas agar dengan adanya kegiatan ini diharapkan dapat memberikan pengetahuan dan pemahaman akan pentingnya berlalu lintas yang baik dan benar, sehingga diharapkan kedepannya peserta penyuluhan/sosialisasi dapat menerapkan pengetahuan tersebut didalam berkendara.

\subsection{Target Luaran}

Adapun target luaran adalah hasil penyuluhan hukum atau sosialisasi yang dilaksanakan tampak pada meningkatkan pengetahuan dan pemahaman peserta didik tentang kesadaran hukum berlalu lintas. Diharapkan kegiatan ini dapat memberikan pengetahuan dan pemahaman akan pentingnya berlalu lintas yang baik dan benar, sehingga harapan kedepannya peserta didik dapat menerapkan pengetahuan tersebut didalam berkendara.

\section{METODE PELAKSANAAN}

Dalam kegiatan pengabdian kepada masyarakat ini adanya teori-teori yang perlu dipahami para peserta. Penyampaian teori tersebut menggunakan metode sebagai berikut:

a. Persiapan Peserta. Peserta penyuluhan hukum yaitu perwakilan tiap kelas X, XI dan XII Siswa SMK Kristen Getsemani Manado yang berjumlah kurang lebih 75 orang bersiap di ruang pertemuan untuk mengikuti kegiatan ini.

b. Pemaparan Materi. Pada tahap ini dilakukan pemaparan materi sosialisasi kesadaran hukum berlalu lintas kepada siswa-siswi SMK Kristen Getsemani Manado.

c. Tanya Diskusi. Pada tahap ini dilakukan sesi tanya jawab. Diberikan kesempatan kepada peserta sosialisasi untuk memberikan pertanyaan terhadap materi yang telah disampaikan.

Beberapa indikator yang diukur dan dinilai dalam penyuluhan hukum tentang kesadaran hukum berlalu lintas, meliputi:

a. Kemampuan memahami maksud, tujuan dan sasaran pelaksanaan kegiatan;

b. Bahan dan peralatan yang digunakan;

c. Terampil mengerjakan;

d. Sikap, apresiasi, nilai-nilai moral.

Mitra dalam kegiatan ini adalah Sekolah Menengah Kejuruan (SMK) Kristen Getsemani Manado. Institusi pendidikan ini membutuhkan penyuluhan hukum untuk dijadikan kompetensi dasar dengan indikator dan materi pembelajaran dan sumber pembelajaran berkaitan mengenai kesadaran hukum dan peraturan lalu lintas, karena banyaknya kegiatan pembelajaran yang 
EDUPRENEUR || Vol. 3, No 1, Maret 2020

Jurnal Pengabdian Kepada Masyarakat Bidang Kewirausahaan

dilaksanakan dalam rangka melatih peserta didik memiliki keterampilan sesuai bidang keahlian.

Dalam pelaksanaan kegiatan ini perlu dilakukan evaluasi untuk mengetahui tingkat keberhasilan kegiatan. Adapun aspek yang akan dievaluasi dalam kegiatan ini, yaitu keaktifan mengikuti selama pelaksanaan kegiatan dan pemahaman serta merumuskan tindakan-tindakan positif yaitu dengan menerapkan pengetahuan berlalu lintas yang baik dan benar didalam berkendara.

\section{HASIL DAN LUARAN YANG DICAPAI}

Masih banyak pelajar-pelajar ini yang diberi keleluasaan oleh orang tuanya untuk mengendarai kendaraan bermotor di jalan raya. Padahal mereka merupakan seseorang yang belum dapat mengendalikan emosi dan belum mengerti tentang berbagai regulasi berlalu lintas. Itulah gambaran pengguna jalan di masyarakat kita.

Faktor-faktor yang menyebabkan kecelakaan diantaranya :

a) Pengguna Jalan yang Tidak Terampil

Skill dalam berkendara sangat dibutuhkan karena untuk menjaga keselamatan dalam berkendara. Seorang pengendara harus dapat menjaga jalur yang dilaluinya, dalam arti jika pengendara ingin melewati kendaraan lain pengendara tersebut harus memperhatikan keadaan kendaraan di samping maupun dibelakangnya. Selain itu, pengguna jalan yang tidak terampil tidak mengetahui jarak aman dan tidak dapat memelihara jalur sehingga terjadi kecelakaan.

Pengguna jalan yang tidak mempunyai Surat Izin Mengemudi mangakibatkan pengguna jalan tersebut tidak paham akan aturan berlalu lintas serta tidak paham akan berbagai regulasi yang telah ditetapkan. Hal tersebut menjadikan para pengguna jalan tidak mematuhi ramburambu lalu lintas dan peraturan yang ada. Sehingga menimbulkan ketidakdisiplinan para pengguna jalan yang mengakibatkan terjadinya kecelakaan lalu lintas.

b) Ketidakmatangan Emosional

Telah dipaparkan oleh penulis bahwa $55 \%$ korban kecelakaan adalah mereka yang berusia produktif. Pengguna jalan yang masih berusia produktif kurang dapat mengendalikan emosi pada dirinya sehingga dalam berkendara melaju dengan kecepatan tinggi tidak sesuai kecapatan ratarata yang tertera pada rambu-rambu lalu lintas. Kecepatan tinggi dapat menyebabkan kecelakaan karena pengendara hanya mempunyai sedikit waktu untuk melihat bahaya dan mengambil tindakan, semakin jauh jarak pengereman yang dibutuhkan, kehilangan kendali kendaraan misalnya jika ada tikungan harus belok kanan karena kehilangan kendali justru belok kiri, dan pengguna jalan lain mungkin salah menilai kecepatan pengendara.

Kecepatan tinggi dapat menghemat sedikit tetapi menimbulkan dana yang besar. Pengguna jalan yang berkecepatan tinggi dapat menghemat waktu dan bahan bakar, namun jika terjadi kecelakaan justru mengakibatkan dana yang besar harus dikeluarkan.

c) Tidak Mengetahui Medan yang Dilewati

Faktor ketidaktahuan pengendara akan medan yang akan dilewati juga merupakan faktor penyebab kecelakaan karena jika tiba-tiba pengguna jalan melewati jalan licin dan rusak pengguna jalan tersebut akan kehilangan keseimbangan dan mengakibatkan terjadinya kecelakaan.

d) Pengaruh Minuman Keras dan Narkoba Minuman keras dan Narkoba mengandung zat yang dapat menghilangkan kesadaran. Pengguna jalan yang kehilangan kesadarannya akan mangalami kecelakaan lalu lintas yang tidak dapat terhindarkan lagi. Karena pengguna jalan yang kehilangan kesadaran sudah tidak dapat mengendalikan laju kendaraannya, tidak dapat mematuhi peraturan dan rambu-rambu yang ada.

Solusi mengurangi tinnginya angka kecelakaan untuk meningkatkan tingkat keselamatan di jalan raya salah satu caranya adalah dengan mengubah paradigma masyarakat. Masyarakat harus dapat memahami bahwa selain skill untuk berkendara tetapi juga pemahaman mengenai peraturan dan etika berkendara. Cara yang dilakukan untuk mengubah paradigma masyaraka misalnya :

a) Turun langsung ke jalan untuk mensoialisasikan akan pentingnya safety ridding.

b) Selalu mengingatkan para pemangku kepentingan untuk ikut serta menciptakan rasa aman dan nyaman di jalan.

c) Mensosialisasikan etika berkendara sejak dini mulai dari tingkat pendidikan TK.

d) Menanamkan 3 istilah yaitu : 
- Rules artinya paham dan taat pada peraturan pemerintah dan undangundang yang berlaku.

- Skill artinya keahlian berkendara dan membaca situasi agar dapat mengahadapi hal tak terduga agar dapat terhindar dari kecelakaan.

- Attitude artinya menghargai sesama pengguna jalan dan paham atas pentingnya keselematan diri dan sekiatrnya.

Selain cara-cara yang telah diuraikan sebelumnya, menurut penulis cara lain untuk mengurangi tingginya angka kecelakaan yaitu :

a) Sosialisasi sejak dini melalui pendidikan mulai dari tingkat TK sampai SMA yang dilakukan oleh pihak yang berwenang, seperti guru maupun pihak kepolisian.

b) Pendidikan lalu lintas diintegralkan dengan mata pelajaran yang berkaitan dengan nilai tersebut. Misalnya mata pelajaran Pendidikan Kewarganegaraan, dan PAI dari tingkat SD sampai Perguruan Tinggi.

c) Mengadakan seminar/workshop dengan tema keselamatan berkendara disekolah-sekolah, kampus, maupun masyarakat umum.

d) Mengadakan lomba- lomba yang berhubungan dengan lalu lintas misalnya Lomba Pemilihan Pelajar Pelopor Keselamatan LLAJ.

Berdasarkan hasil observasi dan evaluasi atas pelaksaanaan kegiatan di peroleh hasil antara lain:

1. Mitra belum cukup mengerti dan memahami berlalu lintas namun memiliki keinginan besar untuk mengetahui dan memahami tentang berlalu lintas serta aturan hukum didalamnya.

2. Pada kegiatan penyuluhan dan sosialisasi berlalu lintas kepada mitra bertujuan agar lebih memahami akan betapa penting pemahaman aturan lalu lintas yang berlaku di Indonesia.
3. Pada akhirnya mitra paham sebab dan akibat melanggar aturan berlalu lintas yang berdampak langsung pada masa depan peserta didik sebagai generasi penerus bangsa.

\section{KESIMPULAN}

Kegiatan sosialisasi pengabdian kepada masyarakat bagi siswa-siswi tentang kesadaran hukum dalam rangka pengetahuan berlalu lintas di SMK Kristen Getsemani Kota Manado, dilakukan dalam bentuk penyuluhan mengenai aturan-aturan lalu lintas yang berlaku di Indonesia, segala bentuk pelanggaran dan dampak pelanggarannya, serta denda yang merupakan sanksi terjadinya pelanggaran. Diskusi atau tanya jawab menjadi salah satu sesi yang ditunggu karena peserta antusias menanyakan hal-hal yang berkaitan dengan lalu lintas yang belum mereka ketahui. Diharapkan setelah mengikuti kegiatan ini peserta sosialisasi dapat menerapkan pengetahuan tentang berlalu lintas yang baik di kehidupan sehariharinya.

\section{REFERENSI}

Meretokusumo, S. (2008). Meningkatkan Kesadaran Hukum Masyarakat.

Soekanto, S. (1992). Kesadaran Hukum dan Kepatuhan Hukum. Jakarta: CV. Rajawali.

Undang-Undang Dasar Negara Republik Indonesia Tahun 1945. (n.d.).

Undang-Undang Nomor 20 Tahun 2003 Tentang Sistem Pendidikan Nasional. (n.d.).

Undang-Undang Nomor 22 Tahun 2009 Tentang Lalu Lintas dan Angkutan Jalan. (n.d.). 